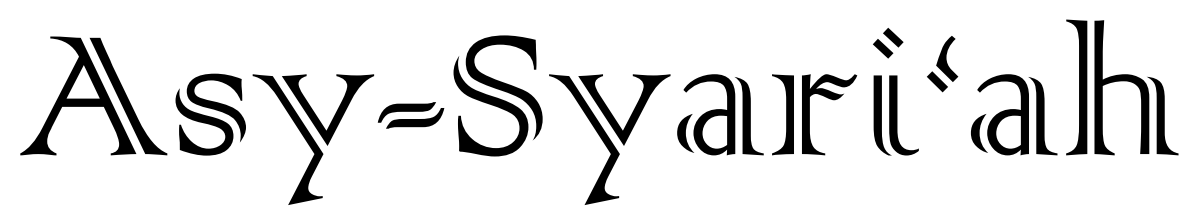

- $\quad$ The Role of Religious Court in Islamic Law Reform in Indonesia

$(125-134)$ Amran Suadi

- Rechtvinding tentang Waris Beda Agama di Pengadilan Agama ( $135-158)$ Kota Bandung Siah Khosyi'ah dan Aan Tsamrotul Fuadah

- Dualisme Kedudukan dan Tanggung Jawab Notaris dalam ( $159-170)$ Tatanan Sistem Hukum Nasional Isis Ikhwansyah dan Indra Prayitno

- Nilai-Nilai Keislaman dalam Konstitusi Kesultanan Ngayogyakarta Hadiningrat

Abdul Rohim Al Wafi

- Anotasi Putusan Dissenting Opinion dalam Putusan Kasasi Taufik Maulani

- Dampak Poligami Siri Terhadap Kehidupan Keluarga di Desa Cigugur Girang, Bandung Barat Ade Darmawijaya

- Azas-Azas dan Landasan Distribusi Pendapatan dalam Islam $(221-232)$ Rani Mulyani dan Iwan Setiawan

- Eksistensi Riba dalam Investasi Wakaf Uang di Luar Bank (233-244) Syari'ah

Khoir Affandi

- Hak Pendidikan bagi Penyandang Disabilitas dalam Perspektif Hukum Perdata dan Hak Asasi Manusia

Ikbar Maulana Malik

- Perspektif Hukum Islam dalam Penyelesaian Sengketa Melalui ( $257-280$ ) Mediasi di Badan Penyelesaian Sengketa Konsumen Kota Mataram Irma Istihara Zain 


\section{Asy-Syauri'ah}

Volume 21, Number 2, 2019

\section{EDITOR-IN-CHIEF}

Ine Fauzia

\section{EDITORIAL BOARD}

Sofyan al-Hakim, UIN Sunan Gunung Djati Bandung, Indonesia Deni Kamaludin Yusup, UIN Sunan Gunung Djati Bandung, Indonesia Meria Utama, Fakultas Hukum Univrsitas Sriwijaya, Indonesia Dewi Mayaningsih, UIN Sunan Gunung Djati Bandung, Indonesia Andrey Sujatmiko, Fakultas Hukum Universitas Trisakti, Jakarta, Indonesia Hetty Hassanah, Universitas Komputer Indonesia, Indonesia

\section{PEER-REVIEWERS}

Muhammad Irfan Helmy, IAIN Salatiga, Semarang, Indonesia Ahmad Ali Nurdin, UIN Sunan Gunung Djati Bandung Tajul Arifin, UIN Sunan Gunun Djati Bandung, Indonesia Mohamad Anton Athoillah, UIN Sunan Gunung Djati Bandung, Indonesia Mrs. Renny Supriyatni, Universitas Padjadjaran, Indonesia Ahmad Tholabi Karlie, UIN Syarif Hidayatullah Jakarta, Indonesia Ija Suntana, UIN Sunan Gunung Djati Bandung, Indonesia Zezen Zaenal Mutaqin, University of California, Los Angeles, United States Ahmad Fathonih, UIN Sunan Gunung Djati Bandung, Indonesia Rahman Syamsuddin, Universitas Islam Negeri Alauddin Makassar, Indonesia

\section{PROOFREADER/DESIGN COVER}

Nanang Sungkawa

\section{LAYOUT EDITOR}

Opik Rozikin

Asy-Syari' ah has been accredited based on the determination of Director General of Research and Development Strengthening, Ministry of Research, Technology and Higher Education of Republic of Indonesia, No. 14/E/KPT/2019 (valid until 2023). 


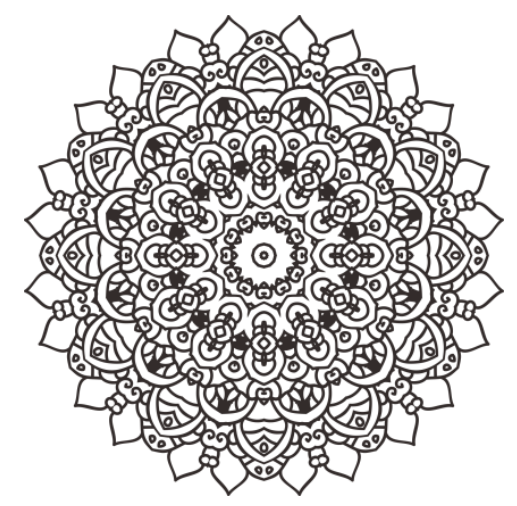

\title{
NILAI-NILAI KEISLAMAN DALAM KONSTITUSI KASULTANAN NGAYOGYAKARTA HADININGRAT
}

\author{
Abdul Rohim Al Wafi \\ Program Magister Hukum Islam Universitas Islam Negeri Sunan Kalijaga \\ Email: abdurrahim.alwavi@gmail.com
}

\begin{abstract}
Many political experts state that the Medina Charter is the first written State Constitution in the World. Several important principles have been laid out in the constitution, namely, equality, justice, freedom of religion, social security and joint responsibility in security. Medina can be seen as a country, because it has met the minimum requirements for the formation of a state, namely: First, the community has a certain area, namely Medina. Second, all groups of people (Muslims, Jews and polytheists) recognize and accept the Prophet as the leader and holder of legal political authority in their lives. Third, the groups that have awareness and desire to live together in order to realize harmony and mutual benefit. Referring to the principles adopted in the Medina Charter, Indonesia and its Yogyakarta Palace certainly have the same constitution for their purposes. Namely maintaining harmony and ensuring social equality. The Yogyakarta Palace has a constitution or legal basis called Paugeran. This paugeran functioned the same as the aim of the Medina charter at that time. Not only arrived at the goal, the field practice also showed that paugeran was able to become a disperse of the tangled threads of the problems that had occurred in Yogyakarta society for a long time, starting from the Giyanti agreement in 1755 .
\end{abstract}

Keywords: yogyakarta, constitution, medina charter, Islamic 
Abstrak: Banyak pakar politik menyatakan bahwa Piagam Madinah merupakan Konstitusi Negara tertulis pertama di Dunia. Beberapa prinsip penting telah diletakkan dalam konstitusi itu, yaitu, persamaan, keadilan, kebebasan beragama, jaminan sosial dan tanggung jawab bersama dalam keamanan. Madinah dapat dipandang sebagai sebuah negara, karena telah memenuhi syarat minimal terbentuknya negara yaitu: Pertama, masyarakat tersebut memiliki wilayah tertentu yaitu Madinah. Kedua, semua golongan masyarakat (Muslim, Yahudi dan orang-orang musyrik) mengakui dan menerima Nabi sebagai pemimpin dan pemegang otoritas politik yang sah dalam kehidupan mereka. Ketiga, golongan-golongan yang ada memiliki kesadaran dan keinginan untuk hidup bersama dalam rangka mewujudkan kerukunan dan kemaslahatan bersama. Mengacu pada prinsip yang diterdapat pada piagam madinah, Indonesia dengan Keraton Yogyakartakatanya tentu memiliki konstitusi yang sama secara tujuan. Yakni menjaga kerukuan dan menjamin kesetaraan sosial. Keraton Yogyakarta memiliki konstitusi atau dasar hukum yang disebut Paugeran. Paugeran ini berfungsi sama seperti tujuan dicetuskannya piagam madinah pada waktu itu. Tak hanya sampai pada tujuan, praktik lapangan juga memperlihatkan bahwa paugeran mampu menjadi pelerai benang kusut permasalahan yang terjadi di masyarakat Yogyakarta sejak lama, terhitung sejak dicetuskannya perjanjian Giyanti pada Tahun 1755.

Kata kunci: yogyakarta, konstitusi, piagam madinah, keislaman 


\section{Pendahuluan}

Persoalan konstitusi menjadi perdebatan yang tidak pernah berakhir di kalangan ahli politik Islam, terutama ketika dihadapkan pada masalah hubungan agama dan negara. Dalam hal ini, ada tiga teori tentang hubungan negara dan agama; Pertama, teori sekularistik yang pada intinya mengatakan bahwa Agama (Islam) tidak ada hubungannya dengan negara. ${ }^{1}$ Model teori politik ini, Negara menghapus seluruh syari'ah Islam dari dasar negaranya. Kedua, teori simbiotik yang menawarkan pandangan bahwa agama dan negara berhubungan satu sama lain secara timbal balik dan saling memerlukan ${ }^{2}$. Model teori politik ini lebih menekankan pada subtansi daripada legal formal bentuk Negara. Ketiga, teori integralistik yang menawarkan konsep bersatunya negara dengan agama ${ }^{3}$. Agama dan negara tidak dapat dipisahkan. Apa yang menjadi habithot (wilayah) agama otomatis menjadi habithot politik. Konsekuensi dari teori politik ini, maka Islam harus menjadi dasar negara, dan syari'ah harus diterima sebagai konstitusi Negara.

Dalam tahap selanjutnya sejarah Islam juga memperlihatkan fluktuasi penerapan berbagai varian model negara konstritusional. Dalam tradisi kesarjanaan Muslim, konstitusi bersumber dari al-Qur'an dan keputusan Nabi saw sering disebut dengan syari'ah.

Di negara-negara modern, konstitusi merupakan suatu yang sangat krusial. Karena ia merupakan pegangan dan pemberi batas atau pengendali kekuasaan dan sekaligus mengatur bagaimana kekuasaan negara harus dijalankan, tidak ada satu negara pun di dunia ini yang tidak mempunyai konstitusi. Negara dan konstitusi merupakan dua hal yang tidak dapat dipisahkan dengan yang lainnya.

Dalam hukum ketatanegaraan Islam (Fiqh Siyasah), konstitusi disebut dengan dusturi (berasal dari bahasa Persia). Setelah mengalami penyerapan ke dalam bahasa Arab, kata dustur berkembang pengertiannya menjadi asas, dasar atau pembinaan. Menurut istilah, dustur berarti kumpulan kaidah yang mengatur dasar dan hubungan kerja sama antara sesama anggota masyarakat dalam sebuah negara, baik yang tidak tertulis (konvensi) maupun yang tertulis (konstitusi) ${ }^{4}$.

Prinsip-prinsip yang diletakkan dalam perumusan konstitusi ini adalah jaminan hak-hak asasi manusia setiap anggota masyarakat dan persamaan kedudukan semua orang di mata hukum tanpa membeda-bedakan klasifikasi sosial, kekayaan, pendidikan dan agama. Menurut ulama figh, pada mulanya pola hubungan pemerintah dengan

\footnotetext{
${ }^{1}$ M. Solihin, Perkembangan Pemikiran Fllsafat dari Klasik hingga Modern (Bandung:CV. Pustaka Setia, 2007), hlm. 246. Istilah dan gerakan ini pertama dikemukakan oleh George Jacob Holyoake (1846).

${ }^{2}$ David L. Sills (ed.), International Encyclopedia of the Social Sciences, Vol. 9, (New York: The Macmillan Company \& The Free Press, 1969), hlm. 387.

${ }^{3} \mathrm{lbid}$. Prof. Kamsi juga menuturkan dalam perkuliahan bahwa teori ini merupakan teori yang sedang dianut dan dibangun oleh pemerintah Indonesia. Lihat juga, Masykuri Abdillah, Hubungan Agama Dan Negara Dalam Konteks Modernisasi Politik Di Era Reformasi (Jurnal Sekolah Pascasarjana UIN Syarif Hidayatullah).

${ }^{4}$ Imam Al-Mawardi, Al-Ahkām al-Sulțāniyyah (Jakarta: Qisthi Press, 2015), hlm. 12. Buku ini dialihbahasakan oleh Khalifurrahman Fath dan Fathurrahman.
} 
rakyat ditentukan oleh adat istiadat (tidak ada batasan yang jelas-memunculkan sikap otoriter dan reaksi dari rakyat). Akibat dari reaksi tersebut, lahirlah pemikiran untuk menciptakan undang-undang dasar atau konstitusi sebagai pedoman dan "aturan main" dalam hubungan antara pemerintah dan rakyat. Sumber utama pembentukan konstitusi dalam hukum Islam adalah alQur'an dan Sunah.

Indonesia memilih bentuk Negara kesatuan sebagaimana tercantum dalam Pasal 1 ayat (1) UUD 1945, "Negara Indonesia adalah negara kesatuan yang berbentuk Republik". Penempatan di awal ini merupakan suatu ketegasan terhadap bentuk Negara Indonesia. Bahkan ada elemen yang mempertahankan bentuk Negara ini yaitu pada Pasal 37 ayat (5), "Khusus mengenai bentuk Negara Kesatuan Republik Indonesia tidak dapat dilakukan perubahan".

Dalam bentuk Negara kesatuan, wilayah dibawahnya terbagi ke dalam provinsiprovinsi, kabupaten/kota, kecamatan, dan sampai tingkat paling rendah yakni kelurahan. Dan Negara juga mengakui adanya daerah yang bersifat khusus. Seperti tertuang dalam Undang-Undang Dasar Negara Republik Indonesia tahun 1945 pasal 18B ayat (1) disebutkan, "Negara mengakui dan menghormati satuan-satuan pemerintah daerah yang bersifat khusus atau istimewa yang diatur dengan undang-undang". pasal tersebut dengan jelas dan tegas menjelaskan bahwa Negara mengakui dan menghormati satuan-satuan pemerintahan daerah yang bersifat khusus atau istimewa. Secara yuridis, bahwa keistimewaan Yogyakarta telah diakui di Negara Indonesia sebagaimana telah tertulis dalam Pasal 18B ayat (1) 1945 tersebut. Dalam undang-undang yang lain, Nomor 22 Tahun 1948 tentang Pemerintahan Daerah Pasal 1 ayat (2) dinyatakan, "Keistimewaan peraturan daerah dalam undang-undang ini hanya mengenai kepala daerahnya dalam pasal 18 ayat (5) dan (6) dimana ditentukan bahwa kepala/wakil kepala daerah Istimewa diangkat oleh pemerintah dari ketrurunan keluarga yang berkuasa di daerah itu dengan syarat-syarat kecakapan, kejujuran, dan dengan mengikat adat-istiadat itu".

DIY merupakan satu dari beberapa daerah istimewa di Negara Indonesia. Melalui UU Nomor 13 Tahun 2012 tentang keistimewaan DIY yang terdiri dari 16 Bab dan 51 Pasal. Dan secara urusan internal kasultanan, Kausltanan Yogyakarta memiliki hukum sendiri yang kemudian terakomodir secara penuh keberadannya dan keberlangsungannya oleh Negara Indonesia melalui UU Nomor 13 Tahun 2012. Hukum kasultanan yang berdasarkan pada warisan kebudayaan - secara turun temurun- dan hukum islam, secara keseluruhan dilegitimasi secara mutlak oleh negara, seperti suksesi, pertanahan, dan anggaran. Ketiga hal tersebut secara penuh menjadi urusan internal keraton menggunakan kenegaran islam yang turun temurun. Menjadi menarik menelisik secara mendalam peranan hukum islam dalam praktik hukum yang dijalankan dalam internal kasultanan Yogyakarta. Dari beberapa sumber diatas pula, jelaslah keberadaan keistimewaan kasultanan Yogyakarta di Negara Kesatuan Republik Indonesia, baik secara de jure maupun de facto. 


\section{Metode Penelitian}

Penelitian ini secara garis besar merupakan penelitian kepustakaan, atau lebih dikenal dengan istilah Library Research. Berkaitan dengan Library Research, sebagaimana dikutip oleh Dyah Octorina Susanti dan Aan Efendi dalam bukunya Penelitian hukum, Soerjono Soekanto dan Sri Mamudji menyebutkan bahwa penelitian hukum kepustakaan disebut juga penelitiaan hukum normatif5, karena dilakukan dengan cara meneliti bahan-bahan pustaka atau data sekunder saja ${ }^{6}$. Penelitian hukum normatif juga disebut sebagai penelitian yang meletakan hukum dalam sebuah bangunan sistem norma. Maksud dari sistem norma adalah mengenai asas-asas, norma, kaidah peraturan perundangan, putusan pengadilan, perjanjian serta doktrin (ajaran). ${ }^{7}$

Pendekatan dalam penelitian hukum normatif merupakan bahan untuk mengawali sudut pandang dan kerangka berpikir peneliti dalam melakukan analisis ${ }^{8}$ serta ekplanasi hukum. ${ }^{9}$ Grand Approach (gerbang utama penelitian) yang digunakan dalam penelitian ini ialah Siyasah Dusturiah (politik kehukuman) dengan menggunakan nilai dan prinsip dalam Piagam Madinah sebagai gerbang utama dalam menganlisa birokrasi kasultanan Yogyakarta dari segi kesejarahan.

Kendatipun demikian, terdapat beberapa complement of approach (pendekatan pelengkap) yang digunakan juga dalam penelitian ini setelah melalui gerbang utama, yakni berupa pendeketan yuridis (peraturan perundang-undangan sebagai dasar analisis penlitian hukum $)^{10}$, politik hukum (memandang politik secara fungsional) ${ }^{11}$, secara historis (berbasis data sejarah), antropologi-historis.

Adapun pendekatan antropologi yang dimaksud memiliki tujuan guna memfokuskan penelitian pada diri perseorangan. Hal demikian disebabkan oleh pemegang kendali sebuah objek kaji penelitian dipegang penuh oleh seorang Sultan. Secara singkat dapat dipahami bahwa antropologi adalah salah satu disiplin ilmu dari cabang ilmu pengetahuan sosial yang memfokuskan kajiannya pada manusia. ${ }^{12}$ Sehingga dapat disimpulkan bahwa penelitian ini menitikfokuskan pada kejadian alamiah pada masa lampau dengan seorang sultan melalui wewenang dan kebijakannya sebagai titik fokus utama.

\footnotetext{
${ }^{5}$ Dyah Octorina Susanti dan Aan Efendi, Penelitian Hukum (Legal Research) (Jakarta:Sinar Grafika, 2014), hlm. 19.

${ }^{6}$ Soerjono soekanto dan Sri Mamudji, Penelitian Hukum Normatif: Suatu tinjauan singkat (Jakarta: Rajawali Pers, 2013), hlm. 13.

7 Fajar Mukti Fajar and Yulianto Ahmad, Dualisme Penelitian Hukum Normatif Dan Empiris (Yogyakarta: Pustaka Pelajar, 2010), hlm. 34 .

${ }^{8}$ lbid., hlm. 184

${ }^{9}$ Johnny. Ibrahim, Teori Dan Metodologi Penelitian Hukum Normatif, Cet. 6. (Malang: Bayu Media, 2012), hlm. 299-300.

${ }^{10}$ Soerjono Soekanto dan Sri Mamudji, op.cit., hlm. 15.

${ }^{11}$ Ramlan Surbakti, Memahami Ilmu Politik, cet. 6 (Jakarta: Grasindo, 2007), hlm. 21

${ }^{12}$ Dedi Mahyudi: Pendekatan Antropologi dan Sosiologi dalam Studi Islam (2016), hlm. 208
} 


\section{Yogyakarta dan Praktik Hukum di Masa Lampau Hingga Hari Ini}

Laman resmi pemerintah provinsi Yogyakarta menuturkan Daerah Istimewa Yogyakarta keberadaannya dalam konteks historis dimulai dari sejarah berdirinya Kasultanan Ngayogyakarta Hadiningrat berdasarkan Perjanjian Giyanti 1755. Berawal dari sini muncul suatu sistem pemerintahan yang teratur dan kemudian berkembang, hingga akhirnya sebagai Daerah Istimewa Yogyakarta yang merupakan suatu bagian dari Negara Kesatuan Republik Indonesia (NKRI). Kasultanan Ngayogyakarta Hadiningrat didirikan pada tahun 1755 oleh Pangeran Mangkubumi yang bergelar Sultan Hamengku Buwono I, sedangkan Kadipaten Pakualaman didirikan pada tahun 1813 oleh Pangeran Notokusumo (saudara Sultan Hamengku Buwono II) yang bergelar Adipati Paku Alam I. ${ }^{13}$

Sejak berdirinya, baik Kasultanan maupun Kadipaten adalah pemerintahan kerajaan yang diakui kedaulatannya. Pada masa kolonial Belanda, pemerintahan di Kasultanan Yogyakarta diatur kontrak politik yang dilakukan pada tahun 1877, 1921, dan 1940, antara Sultan dengan Pemerintah Kolonial Belanda. Hal ini menunjukkan bahwa Keraton tidak tunduk begitu saja kepada Belanda. Pemerintah Hindia Belanda mengakui Kasultanan Ngayogyakarta Hadiningrat dan Kadipaten Pakualaman sebagai kerajaan yang berhak mengatur dan mengurus rumah tangga pemerintahannya sendiri yang dikenal dengan istilah zilfbesturende landschappen ${ }^{14}$. Kontrak politik terakhir Kasultanan Ngayogyakarta tercantum dalam Staatsblaad 1941 Nomor 47, sedangkan kontrak politik Kadipaten Pakualaman dalam Staatsblaad 1941 Nomor 577.

Pada masa pendudukan Jepang, Yogyakarta diakui sebagai Daerah Istimewa atau Kooti dengan Koo sebagai kepalanya, yakni Sri Sultan Hamengku Buwono IX. Di bawah Kooti, secara struktural ada wilayah-wilayah pemerintahan tertentu dengan para pejabatnya. ${ }^{15}$

Setelah Proklamasi Kemerdekaan Republik Indonesia (RI), Sri Sultan Hamengku Buwono IX dan Sri Paku Alam VIII menyatakan kepada Presiden RI bahwa Daerah Kasultanan Ngayogyakarta Hadiningrat dan Daerah Kadipaten Pakualaman menjadi wilayah Negara RI, bergabung menjadi satu kesatuan yang dinyatakan sebagai Daerah Istimewa Yogyakarta (DIY). Sri Sultan Hamengku Buwono IX dan Sri Paku Alam VIII sebagai Kepala Daerah dan Wakil Kepala Daerah bertanggung jawab langsung kepada Presiden RI. Hal tersebut dinyatakan dalam: ${ }^{16}$ PertamaPiagam Kedudukan Sri Sultan Hamengku Buwono IX dan Sri Paku Alam VIII tertanggal 19 Agustus 1945 dari Presiden RI. Kedua, Amanat Sri Sultan Hamengku Buwono IX dan Sri Paku Alam VIII tertanggal 5 September 1945 (dibuat secara terpisah) dan Ketiga, Amanat Sri Sultan Hamengku Buwono IX dan Sri Paku Alam VIII tertanggal 30 Oktober 1945 (dibuat dalam satu naskah).

\footnotetext{
${ }^{13}$ Website pemda DIY

${ }^{14}$ Dalam Serat Angger Pradata Awal dan Pradata Akir di Kraton Yogyakarta, hal 1

${ }^{15}$ Jurnal Suhatno pada pembekalan budaya Yogyakarta, hal 3

${ }^{16} \mathrm{lbid}$
} 
Keunikan pengalaman Yogyakarta merupakan salah satu fakta yang menjadikannya sebagai daerah istimewa. Salah satu keunikan yang telah dilalui oleh pemerintahan Yogyakarta ialah Yogyakarta merupakan wilayah yang telah ada sebelum Indonesia merdeka, hal demikian yang menjadikan wilayah Yogyakarta lebih dikenal terlebih dahulu dari pada istilah Indonesia. Selain itu, Yogyakarta juga memiliki sejumlah sejarah berdirinya kerajaan yang berkaitan dengan tanah dan kewilayahan tersendiri tanpa adanya pembagian oleh negara Indonesia. Dalam proses perkembangan pemerintahannya, Yogyakarta berproses dari tipe pemerintahan feodal dan tradisional menjadi suatu pemerintahan dengan struktur modern.

Dalam perkembangan dan dinamika negara bangsa terdapat keterkaitan yang erat antara Republik Indonesia dan DIY. Entitas DIY mempunyai aspek politis-yuridis berkaitan dengan sejarah berdirinya yang merupakan wujud pengintegrasian diri dari sebuah kerajaan ke dalam Negara Kesatuan Republik Indonesia.

Undang-Undang Nomor 3 Tahun 1950 tentang Pembentukan Daerah Istimewa Yogyakarta merupakan respons atas eksistensi DIY dan juga merupakan pengakuan kewenangan untuk menangani berbagai urusan dalam menjalankan pemerintahan serta urusan yang bersifat khusus. Undang-Undang ini telah diubah dan ditambah, terakhir kali dengan Undang-Undang Nomor 9 Tahun 1955 (Lembaran Negara Tahun 1959 Nomor 71, Tambahan Lembaran Negara Nomor 1819) yang sampai saat ini masih berlaku. Dalam Undang-Undang tersebut dinyatakan bahwa DIY merupakan daerah setingkat provinsi dan meliputi bekas Daerah Kasultanan Ngayogyakarta Hadiningrat dan Daerah Kadipaten Pakualaman. Pada setiap Undang-Undang yang mengatur Pemerintahan Daerah, dinyatakan keistimewaan DIY tetap diakui.

Dalam rangka perubahan dan penyesuaian serta penegasan Keistimewaan DIY Pemerintah telah menetapkan Undang-Undang Nomor 13/2012 Tentang Keistimewaan DIY yang disahkan 31 Agustus 2012 dan diundangkan pada tanggal 3 September 2012. Pengaturan Keistimewaan DIY bertujuan untuk mewujudkan tata pemerintahan yang baik dan demokratis, ketentraman dan kesejahteraan masyarakat, menjamin kebhineka-tunggal-ika-an, dan melembagakan peran dan tanggung jawab Kasultanan dan Kadipaten dalam menjaga dan mengembangkan budaya Yogyakarta yang merupakan warisan budaya bangsa. Pengaturan tersebut berlandaskan atas pengakuan atas hak asal-usul, kerakyatan, demokrasi, kebhineka-tunggal-ika-an efektivitas pemerintahan, kepentingan nasional dan pendayagunaan kearifan lokal. Oleh karenanya dengan memperhatikan aspek historis, sosiologis, dan yuridis substansi Keistimewaan DIY diletakkan pada tingkatan pemerintah provinsi.

Kewenangan dalam urusan Kestimewaan seperti yang tertuang dalam UndangUndang Nomor 13 Tahun 2012 Pasal 7 ayat 2 meliputi: tata cara pengisian jabatan, kedudukan, tugas dan wewenang Gubernur dan Wakil Gubernur; kelembagaan Pemerintah Daerah DIY; kebudayaan; pertanahan; dan tata ruang. Dengan demikian, Pemerintah 
Daerah mempunyai kewenangan yang meliputi kewenangan urusan Keistimewaan berdasarkan Undang-Undang Nomor 13 Tahun 2012 dan kewenangan berdasarkan Undang-Undang Nomor 32 Tahun 2004 tentang Pemerintah Daerah. Sesuai dengan UU No 32 tahun 2004, maka posisi DIY sebagai daerah yang setara dengan provinsi mengandung arti bahwa Gubernur merupakan Kepala Daerah Otonom dan sekaligus wakil pemerintah pusat di daerah.

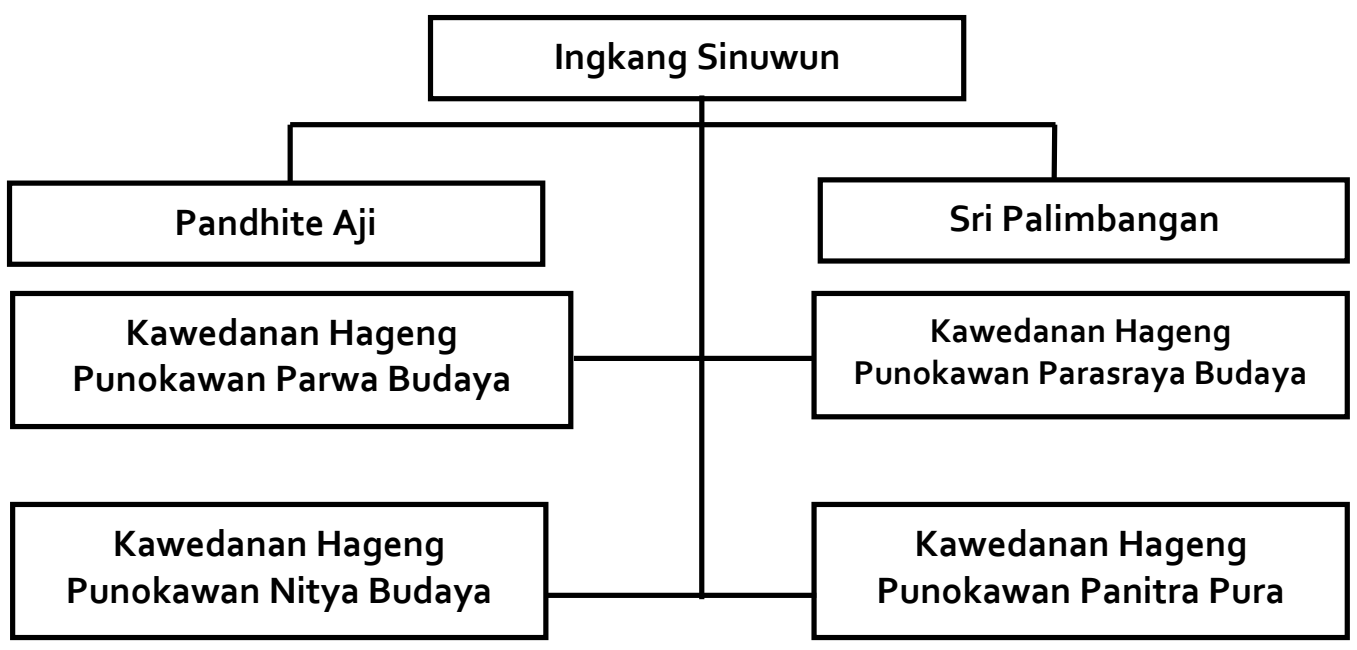

Gambar 1. Tata Rakit Peprintahan Kasultanan Yogyakarta

Secara teknis, rerakit ini diakui keberadaan dan fungsinya oleh UU Nomor 13 Tahun 2012. Bentuk pengakuannya ialah bahwa dalam pengajuan calon gubernur sebelum pelantikan raja sebagai gubernur, kasultanan wajib menyerahkan serat yang membuktikan bahwa sultan yang sedang menjabat merupakan sultan yang sah secara hukum kasultanan. Serat tersebut wajib di tandatangani oleh Penghageng Kawedanan Hageng Punokawan Panitra Pura. Sebelum serat tersebut terbit, harus mendapatkan serat pemberitahuan (tembusan/mengetahui) dalam bentuk paraf dari Pandhite Aji sebagai dewan pertimbangan keagamaan, hukum, dan kerohanian, dan Sri Palimbangan selaku dewan pertimbangan kebijakan secara hukum internal keraton.

Seperti yang telah kita tahu bersama, bahwa secara singkat konstitusi adalah aturan atau hukum yang berlaku dan tercatat secara resmi di suatu daerah, baik tingkat regional, nasional, maupun internasional. ${ }^{17}$ Sifat keberlakukan konstitusi tentu terbatas oleh ruang dan waktu. Jika ditinjau pada sejarah Nabi ketika di Madinah, Nabi yang kapasitasnya sebagai penjelas terhadap ayat al-Qur'an, dalam menghadapi masyarakat Madinah yang majemuk antara golongan Muslim dan non Muslim, khususnya kaum Yahudi, Nabi membuat perjanjian tertulis dengan mereka, yakni piagam Madinah. Isi perjanjian itu, terutama menitikberatkan persatuan kaum Muslimin dan kaum yahudi, menjamin kebebasan beragama bagi semua golongan, menekankan kerjasama, persamaan hak dan kewajiban di antara semua golongan dalam mewujudkan pertahanan 
dan perdamaian, dan mengikis segala bentuk perbedaan pendapat yang timbul dalam kehidupan bersama ${ }^{18}$.

Secara prinsipil, dasar konstitusi dalam islam telah tertuang dalam alqur'an secara implisit. Alqur'an telah menggariskan prinsip-prinsip dasar berupa seperangkat nilai etika untuk dijadikan bahan rumusan konstitusi sebagai landasan bagi kehidupan bernegara. Namun kerjasama kebangsaan pertama kali yang menandai peradaban baru yang dilakukan oleh Rasulullah saw yang berkenaan dengan sistem bernegara ialah dengan menyusun piagam madinah ${ }^{19}$. Dalam piagam tersebut dituliskan dengan jelas hak-hak dan kewajiban pihak-pihak yang ada saat itu untuk bersama-sama menjaga kerukunan seperti yang dipaparkan sebelumnya. Menurut Kamsi ${ }^{20}$ terdapat prinsip-prinsip yang tertuang dalam piagam madinah yang selanjutnya bisa diaplikasikan kedalam praktik bernegara modern, yakni. Pertama, prinsip persaudaraan sesama manusia dalam kehidupan bernegara berimplikasi pada timbulnya persatuan yang kokoh dan toleransi beragama di antara warga yang majemuk. Kedua, prinsip persamaan antar manusia berimplikasi pada pelaksanaan musyawarah dan tegaknya keadilan. Ketiga, prinsip kebebasan manusia mengimplementasikan kepada kebebasan berpikir, dan kebebasan beragama. Oleh sebab itu, hak-hak individu dijamin, kepercayaan dan keyakinan warga Negara tetap dijunjung tinggi. Keempat, mengambil keputusan sendiri.

Namun perlu dimengerti pula bahwa suksesi Kasultanan Yogyakarta berlangsung tetap selama berabad-abad dengan menggunakan maskulinitas gender merupakan bagian dari paugeran adat. Dengan kata lain, paugeran adat adalah sumber hukum Kasultanan Islam seperti Kasultanan Ngayogyakarta Hadiningrat berdasarkan al-Qur'an, al-Hadits, ijma' (kesepakatan ulama), qiyas (penafsiran ulama), 'urf(tradisi budaya) dalam Islam.

Paugeran adalah konstitusi internal kasultanan Yogyakarta. Padanan kata lainnya dari paugeran adalah pathok atau pathokan. Di antara arti kata pathokan adalah dasar hukum dan sesuatu yang tidak dapat ditawar-tawar lagi. Dari itu semua keterangan dan penjelasan tersebut disimpulkan oleh KRT. H. Jatiningrat ${ }^{21}$ bahwa paugeran itu bukan untuk kepentingan pribadi dan bersifat tetap. Berikut penulis paparkan sekelumit nilainilai dan prinsip keislaman dalam konstitusi Kasultanan Yogyakarta berdasarkan naskah konstitusi Yogyakarta dalam buku Kraton Surakarta dan Yogyakarta 1769-1874 ${ }^{22}$.

${ }^{18}$ Kamsi, di sampaikan pada orasi ilmiah dalam Seminar Teori-Teori Konstitusi Dan Pemerintahan Dalam Islam.

${ }^{19}$ Kamsi.

${ }^{20} \mathrm{Ibid}$

${ }^{21}$ Pengageng tepas dwarapura Kasultanan NgaYogyakarta

${ }^{22}$ Buku ini di susun oleh S Margana dan memuat tentang Arsip yang berupa angger-angger kedua kerajaan tersebut dari masa ke masa. Angger-angger tersebut kini, di kasultanan Yogyakarta, berposisikan sebagai Paugeran. Paugeran adalah hukum keraton yang secara mutlak harus dijalankan oleh warga keraton, termasuk Sri Sultan. Paugeran biasanya berbentuk hikayah atau arsip-arsip ketetapan yang bisa dijadikan acuan dan pedoman pada masa kini. 


\section{Persaudaraan Sesama Manusia}

Dalam surat perintah dari Adipati Danureja (IV) atas nama panembahan Hamangkurat di bab I disebutkan "Kepala distrik yang tertinggi harus bertempat di tengah-tengah desanya sendiri, supaya semua perintah dapat segera dilaksanakan, rumah yang ditempati harus berada di tanah lungguhnya masing-masing. ...".

Menurut pada salah satu ayat paugeran diatas, dapat dipahami bahwa petinggi keraton yang bertugas di tatanan masyarakat harus sangat dekat dengan rakyat sehingga akan dengan mudah mengawasi dan mengendalikan kerukunan rakyat. Dalam praktiknya yang berjalan hingga hari ini, kerukunan merupakan asas yang dijalankan dalam bersosial tanpa memandang latar belakang yang di sandang oleh rakyat Yogyakarta. Kerukunan dihasilkan melalui prinsip pandangan hak dan kewajiban antar sesama yang kemudian akan memunculkan kekerabatan sosial.

Menurut KRT Jatiningrat ${ }^{23}$, paugeran baik yang tertulis maupun tidak tertulis menjamin dan memerintahkan warga Yogyakarta yang berstatus warga Yogyakarta atau hanya sekedar penduduk Yogyakarta untuk menjaga persaudaraan antar sesama. Hal tersebut berdasar pada pandangan filosofis keraton ngayogyokarto hadiningrat yang mengatakan, "guyub rukun ing pandum". Hal tersebut dibuktikan oleh hukum yang disusun di keraton, baik berbentuk Angger maupun Sabda ndalem, yang memerintahkan bahwa dilarang adanya pertikaian yang berlarut-larut di daerah Yogyakarta. Sebagai penjaga keharmonisan dalam bersaudara, keraton menjalankan hukum yang berlaku di daerah kekuasaannya oleh eksekutif yakni Sri Sultan HB yang dibantu oleh Pandhite Aji. Pandhite Aji bertugas untuk menyusun hukum yang ada di keraton dan menjalankan atas intruksi Sri Sultan HB. Pandhite aji ini memiliki tugas fungsi seperti demikian sejak bergabungnya Kasultanan Ngayogyokarto Hadiningrat pada Republik Indonesia. Sebelum bergabung dengan RI, tugas penyusun UU dan Kehakiman masih dijalankan oleh Adhyaksa, dengan produk hukumnya yang mengurusi di bidang kerukunan warga dan penduduk bernama Paraparampradhoto.

Diperkuat oleh KRT Purwodiningrat ${ }^{24}$ menjelaskan bahwa produk hukum yang berlaku di Kasultanan tidak semua tertulis. Hal tersebut dikarenakan, menurut pada perjanjian Giyanti, Kasultanan Ngayogyokarto bergerak di Bidang Budaya dan diberikan daerah kekuasaan di daerah pusat kota (red: sekarang Kota Madya Yogyakarta) yang notabene masyarakat plural dan modern. Akibatnya, hukum yang dijalankan di kasultanan Yogyakarta bersifat turun temurun, konservatif, dan lekat dengan budaya. Ketiga unsur itulah yang menjadi ciri khas utama Paugeran hingga saat ini.

${ }^{23}$ Pengageng tepas dwarapura, atau lebih dikenal dengan Romo Tirun. Saat diwawancarai di kantornya beliau berusia 74 tahun dan merupakan sepupu dari Sri Sultan HBX.

${ }^{24}$ Pengageng II Tepas KHP Widyabudaya Kasultanan Yogyakarta 


\section{Persamaan antar manusia}

Dalam surat perintah dari Adipati Danureja (IV) atas nama panembahan Hamangkurat di bab $\mathrm{V}$ disebutkan "Apabila ada orang desa atau bekel desa mempunyai perkara sampai terjadi peperangan atau perkelahian, kepala distrik harus memperingatkan jangan sampai menjadi peperangan atau perkelahian, dan perkara tersebut harus diselesaikan apabila perkara tersebut besar sampai harus menjadi urusan pengadilan kerajaan, kepala distrik segera melaporkannya kepada parentah ageng dan menyerahkan kedua orang yang berselisih tersebut, demikian juga apabila ada orang yang mempunyai keinginan aneh dipandang dari ajaran agama islam yang sudah berlaku atau dipandang dari kebiasaan yang sudah berlaku di kerajaan Yogyakarta, kepala distrik harus segera melaporkan kepada pemerintah supaya segera diperiksa...."

Dapat dipahami bahwa kesamaan antar sesama sangat dijunjung tinggi dan tidak adanya perlakuan khusus bagi salah satu warga. Menurut pasal paugeran diatas, semua warga dipandang sama dalam perlakuan hukum. Pada pasal tersebut juga tidak memandang adanya pengkhususan suku, ras, dan agama. Meski demikian, perlu dipertegas dan diperjelas bahwa suku resmi Yogyakarta adalah Jawa, ber-raskan JawaMelayu dan beragama Islam.

Selain itu, yang berkaitan dengan persamaan terdapat pula dalam naskah nomor 84.1 bab IV disebutkan,"...tanaman yang dapat memberi keuntungan bagi rakyat kecil". Dan dalam bab VIII disebutkan "jangan sampai ada pungutan denda atau pungutan lainnya kepada rakyat kecil".

Dapat dipahami pula bahwa kasultanan tidak memberatkan rakyatnya dari segi materi, baik berupa upeti maupun pajak bumi. Seperti dituturkan oleh KRT. Purwodiningrat bahwa keraton tidak mewajibkan rakyat untuk secara rutin atau tidak rutin memberikan sesuatu pada pihak keraton. Namun meski demikian, masih ada hingga saat ini warga Yogyakarta yang datang ke keraton hanya untuk memberikan hasil bumi atau bentuk yang lain. Jumlah pemberian warga Yogyakarta tersebut memiliki skala yang variatif, yang sedikit hingga banyak. Namun yang perlu dipertegas bahwa pemberian tersebut tidak mengikat dan tidak ada intruksi dari pihak keraton. Pemberian tersebut dilakukan secara sukarela dan atas dasar kehendak sendiri dari pemberi.

Pun dalam produk hukum kontemporer seperti disebutkan pula dalam pergub DIY Tahun 2017 Pasal 4 tentang Tujuan pemanfaatan Tanah Desa adalah untuk: " $a$. Pengembangan kebudayaan; b. kepentingan sosial; c. kesejahteraan masyarakat; dan d. Penyelenggaraan pemerintahan desa."

Sudah sangat jelas, melalui pasal diatas, bahwa persamaan hak dan kewajiban, prioritas dimata hukum, dan kesetaraan dijamin oleh pemerintah DIY. Menurut Romo Tirun, pasal diatas ayat "a" berdasar pada filosofi bahwa salah satu keistimewaan Yogyakarta adalah dari segi budaya yang telah berlangsung sejak perjanjian Giyanti. 
Adapun ayat-ayat lainnya berangkat dari kebutuhan dan tuntutan saat ini yang memang berkembang dan mengharuskan adanya perhatian khusus terhadap kepentingan sosial, kesejahteraan masyarakat, dan penyelenggaraan birokrasi.

Lebih lanjut, Romo Tirun menjelaskan bahwa dalam Angger pradoto dan Angger Pidono, tidak disebutkan adanya pembedaan atau pengkhususan terhadap masyarakat tertentu. Bahkan, lanjutnya, ada hukuman yang lebih berat bagi abdi dalem yang melanggar Angger yang berlaku. Hal tersebut dikarenakan sosok abdi dalem yang wajib menjadi contoh bagi masyarakat, baik dari tutur kata maupun tingkah laku.

\section{Kebebasan manusia}

Dalam naskah Nomor 84.2 bab II menyebutkan "para kepala distrik harus menjaga ketentraman distrik,..." dan bab XIV "semua kepada distrik harus menjaga jalan besar dan kecil serta jembatan..." yang dilanjutkan dengan redaksi "menghilangkan kekhawatiran orang yang berjalan,..."

Berdasar pada paugeran diatas, bahwa kebebasan berinteraksi dan bersosial telah dijamin oleh keraton dengan cara menjamin keamanan dan keselamatan. Dijelaskan oleh KRT. Purwodiningrat dan diperkuat oleh KRT. Jatiningrat bahwa keraton sangat menghargai perbedaan yang ada di masyarakat dan dalam internal keraton sendiri. Sri Sultan memahami bahwa keraton sejak dulu merupakan pelaksana sistem tata Negara dengan berbasis pada suku, budaya, dan bangsa. Akibatnya, perbedaan dari segi agama dan cara berinteraksi merupakan hal yang lumrah dijumpai di Yogyakarta. Meski demikian, keraton tetap memiliki protokol sendiri yang berlaku bagi seluruh abdi dalem yang tertuang dalam paugeran budaya.

Ditilik dari segi agama, secara resmi dan formal, agama resmi keraton Yogyakarta adalah agama islam yang bermadzhabkan syafi'i. Adapun kultur keagamaan keraton bersifat pendialogan antara budaya dan ajaran islam dengan tidak mengurangi dan memodifikasi ajaran islam. Dan secara relasi keagamaan, menurut Romo Tirun, keraton lebih dekat dengan organisasi masyarakat sosial-agama nahdlatul ulama (NU). Menurut pandangannya, organisasi masyarakat tersebut lebih mampu mendialogkan antara ajaran dan budaya sehingga mampu menciptakan praktik agama yang nyaman dan dapat diterima masyarakat secara budaya. Dari efek paugeran tersebut, menjadi hal wajib bahwa keluarga sultan dan pemimpin keraton beragama islam.

Meski demikian, tidak ada larangan bagi masyarakat dan abdi dalem untuk memeluk agama selain islam. Hal tersebut dibuktikan dengan sabda dalem yang tidak membedakan hak dan kewajiban bagi seluruh masyarakat. Bahkan KRT Purwodiningrat mengatakan bahwa tidak ada keharusan beragama Islam ketika hendak atau berkeinginan menjadi abdi dalem. Hal tersebut dikarenakan abdi dalem merupakan jabatan fungsional yang bisa dijalankan oleh siapa saja dengan berpegang teguh pada prinsip kesejahteraan dan kemakmuran keraton dan masyarakat. 


\section{Mengambil Keputusan Sendiri}

Dalam surat perintah dari Adipati Danureja (IV) atas nama panembahan Hamangkurat di bab VI disebutkan "Kepala distrik tidak diperbolehkan menyakiti orang, mengikat, memasung, dan sebagainya kecuali penjahat seperti pencuri, perampok, penipu dan sebagainya...."

Dari pasal tersebut, keraton melegalkan pengambilan keputusan sendiri oleh pemangku kebijakan. Meski demikian, hal tersebut tidak serta merta bebas dilakukan kapan saja. Hak tersebut hanya berlaku bila keadaan sedang arubiru atau kurang kondusif seperti digambarkan pada pasal diatas. Dan tetap masih dalam koridor batasan dalam menindak, yakni hanya tatkala terjadi kekacauan yang bersifat luar biasa. Pada prinsipnya, kekacauan akan masuk pada kategori luar biasa manakala telah masuk pada ranah perampasan hak orang lain dengan cara yang tidak baik dan menimbulkan keresahan ditengah masyarakat.

Disamping itu, paugeran juga sangat melegalkan pengambilan keputusan sendiri ditangan pemangku kebijakan, terlebih Sri Sultan HB. Hal tersebut ditujukan agar hal-hal yang tak di inginkan agar dapat segera ditangani dan ditindak tanpa harus melalui proses panjang dan menghabiskan banyak biaya, tenaga, dan pikiran. Sebagai contoh, sabda dalem yang sudah berubah menjadi intruksi pemerintah DIY ialah pelarangan warga nonpribumi untuk memiliki tanah di Yogyakarta. Peraturan tersebut merujuk pada sejarah panjang bahwa pertama kali yang melakukan babad alas di hutan Pabringan, yang saat ini DIY, adalah kakek atau leluhur dari sri HB I sehingga menjadi wajar apabila secara kepemilikan tanah DIY (kecuali Kulon Progo) atas nama keraton. Hal tersebut dimaksudkan agar warga Yogyakarta bisa dengan aman dan nyaman, terutama kalangan ekonomi menengah kebawah, memiliki dan mengelola tanah Yogyakarta sehingga kemakmuran warga akan terjaga lama dan keberlangsungan kasultanan akan terus bertahan hingga waktu yang amat lama.

Contoh lain dari paugeran yang kemudian telah berubah menjadi angger dalam bentuk sabda raja ialah penegasan status keraton. Sri Sultan HB IX pada tahun 1980 pernah mengeluarkan sabda raja yang berbunyi:

"mengenai masa depan kesultanan Yogyakarta sendiri akan berjalan terus seperti ratusan tahun sebelumnya. Artinya, kesultanan akan tetap ada sebagaimana kesultanan Cirebon dan lain-lain dengan seorang Sultan yang bertahta dan berfungsi sebagai kepala keluarga keraton. Tetapi apakah Sultan juga merupakan gubernur, Kepala DIY, sebagaimana tercantum dalam UU tentang daerah istimewa itu terserah nanti"

Merujuk pada ketetapan diatas dan berkaitan dengan hukum dan keberlangsungan kasultanan Yogyakarta, KRT Jatiningrat menuturkan beberapa hal. 
Pertama, Eksistensi kesultanan akan tetap ada dan terjaga sebagaimana terjadi pada tahun-tahun sebelumnya. Hal demikian memberikan efek pada seluruh warga keraton untuk terus menjaga dan melestarikan keraton beserta seluruh paugeran dan angger-angger nya. Kedua, Kepala keluarga keraton dipegang oleh seorang Sultan dan bertempat tinggal di keraton ngayogyokarto. Hal demikian memberikan efek pada seluruh warga keraton untuk tunduk dan patuh pada Sultan dan memposisikan sultan sebagai centries-value.

Ketiga, Sultan adalah seorang laki-laki. Hal demikian didasarkan pada redaksi, "dengan seorang Sultan yang bertahta dan berfungsi sebagai kepala keluarga keraton". Perbendaharaan kata dan diksi yang dimiliki oleh kebudayaan jawa keraton memiliki banyak sekali kata dan makna. Sehingga antara satu kata dengan kata lain tidak memiliki makna yang timpang tindih. Dari dasar itulah simpulan bahwa sultan wajib dipegang oleh seorang laki-laki didapatkan. Kata Sultan menunjukan pada gender maskulinisme dan mengarah pada satu jenis kelamin, yakni laki-laki. Sedangkan ada pasangan dari kata tersebut, yakni Sultanah. Selain berdasar pada perbendaharaan kata seperti yang dijelaskan, simpulan bahwa seorang sultan harus laki-laki juga didapatkan dari pendekatan filosofis dari redaksi 'berfungsi sebagai kepala keluarga'. Sudah jelas bahwa secara ideal dan lumrah bahwa kepala keluarga merupakan seorang laki-laki dan biasa disebut sebagai 'Bapak'.

\section{Sultan mengakui keberadaan dan fungsi NKRI secara penuh}

Selanjutnya adalah kebijaksanaan sultan HB IX untuk menetapkan siapa yang akan menjadi putra mahkota untuk nantinya diangkat menjadi sultan berikutnya. Untuk keraton Yogyakarta pada waktu itu putra mahkota belum ditentukan secara final. Tetapi petunjuk ke arah itu telah diberikan ketika putra Sri Sultan HB IX yang tertua yakni Herjuno Darpito, yang tahun itu berusia 36 tahun, ditetapkan menjadi Gusti Pangeran Haryo Mangkubumi ${ }^{25}$.

Mengenai pengangkatan putra mahkota, Sri Sultan HB IX menuturkan, terus terang, apabila seorang telah diberi gelar mangkubumi, itu adalah langkah pertama ia dicalonkan untuk menjadi putra mahkota. Tetapi apakah ia benar-benar akan menjadi putra mahkota, masih tergantung penilaian, atau katankalah periode ia menjadi mangkubumi adalah periode penjajagan. Saya menilaianya, para keluargapun menilainya, untuk nanti pada pertemuan keluarga, sebagaimana waktu saya dulu, ditetapkan apakah ia bisa diterima atau tidak sebagai putra mahkota'.

Adapun praktik dari paugeran yang yang sedang hangat untuk dijadikan kajian ilmiah ialah mengenai suksesi kepemimpinan Sri Sultan HB X dan suksesi paugeran itu sendiri. Sri Sultan HB X telah mengeluarkan titah nya dengan bentuk sabda ndalem untuk

${ }^{25}$ Buku Tahta untuk Rakyat (1982). Hal 123 
mengangkat keturunan tertuanya, GKR Pembayun, untuk menjadi putra mahkota dengan menyandang gelar Mangkubumi sejak 5 Mei $2015^{26}$.

GKR Pembayun atau yang sekarang menjadi GKR Mangkubumi merupakan anak tertua Sri Sultan HB X dan GKR Hemas dan beliau adalah seorang perempuan. Sri sultan memiliki anak 5 orang dan kesemuanya perempuan.

Dari data diatas, di sisi lain, Sri Sultan HB X keluar jalur dari paugeran yang telah lama dijalankan dan berlaku di keraton. Pasalnya, baru kali ini seorang perempuan menjabat sebagai Mangkubumi.

Jika hendak dilihat dari segi sejarah, kejadian yang serupa pernah dialami oleh Sri Sultan HB V yang kala itu tidak memiliki keturunan laki-laki. Suksesi kepemimpinan Sri Sultan HB $\vee$ beralih pada adik kandung tertuanya, yang kemudian diangkat menjadi Sri Sultan HB VI. Dari paugeran tersebut, hakikinya Sri Sultan HB X dapat meniru dan mempraktikan dengan cara menjadikan KGPH. Hadiwinoto, adik kandung tertua Sri Sultan HB X, sebagai putra mahkota yang kelak meneruskan suksesi kepemimpinanya di keraton.

\section{Kesimpulan}

Setelah melihat dan memahami pemaparan diatas, maka penulis berkesimpulan bahwa pada Kesultanan Yogyakarta dengan menggunakan pisau analisis keislaman dengan indikator persaudaraan, persamaan, kebebasan, dan pengambilan keputusan telah layak dikualifikasikan sebagai birokrasi islami. Dalam kaitannya dengan UU Nomor 13 Tahun 2012 (UUK DIY) yakni paugeran secara sah diakui dan diakomodir oleh UU tersebut untuk menjalankan pemerintahan keraton yogyakarta yang pada berikutnya akan menjadi melahirkan pemimpin pemerintahan modern; gubernur. Dalam UU Nomor 13 Tahun 2012 itu juga termuat bahwa pengisian jabatan gubernur diisi oleh sultan yang sedang bertahta. Dan sultan yang bertahta, menggunakan hukum yang disebut paugeran. Maka dengan kata lain, UUK DIY akan terlaksana setelah paugeran terlaksana di kasultanan Yogyakarta.

Paugeran, selain karena memang menjadikan alquran, hadits, ijmak, dan qiyas yang notabene milik Islam secara riil dan orsinil sebagai dasar pemutusan perkara, juga karena dalam pelaksanaan yang sangat menjunjung tinggi hak asasi kemanusiaan dan kerukunan. Hal tersebut dapat dilihat dari paugeran dan angger-angger yang berlaku di kesultanan hingga saat ini. Seperti angger pradhoto, angger pidono, angger arubiru.

${ }^{26}$ Setelah kajian dokumen dan wawancara bersama Raden Riyo Kintoko Sri Soedarmo, kepala administrasi Panitra Pura 


\section{DAFTAR PUSTAKA}

Ibrahim, Johnny. Teori Dan Metodologi Penelitian Hukum Normatif. Cet. 6. Malang: Bayu Media, 2012.

Jati, W. R. Kultur Birokrasi Patrimonialisme dalam Pemerintah Provinsi Diy. Jurnal Borneo Administrator, 145-160. 2012.

Jatiningrat, K.H. Merajut Mataram untuk Indonesia. Yogyakarta: Shalahuddiningrat. 2017. Jatiningrat, K. H. (2018, November 14). Birokrasi Kasultanan Yogyakarta. (A. R. Wafi, Pewawancara)

Mahyudi, Dedi. Pendekatan Antropologi dan Sosiologi dalam Studi Islam. t.t. tpn. 2016.

Margana, S. Kratorn surakarta dan Yogyakarta 1769-1874. Yogyakarta: Pustaka Pelajar. t.thn.

Mukti Fajar, Fajar, and Yulianto Ahmad. Dualisme Penelitian Hukum Normatif Dan Empiris. Yogyakarta: Pustaka Pelajar, 2010.

Purwodiningrat, K. (2018, November 5). Birokrasi Kasultanan Yogyakarta. (A. R. Wafi, Pewawancara)

Roem, M. Tahta Untuk Rakyat. Jakarta: PT. Gramedia. 1982.

Soedarmo, R. R. (2018, November 28). Birokrasi Kasultanan NgaYogyakarta. (A. R. Wafi, Pewawancara)

Soekanto, Soerjono., \& Mamudji, Sri. Penelitian Hukum Normatif (Suatu Tinjauan Singkat. Jakarta: Rajawali Perss. 2013.

Suhatno. Jogjakarta dalam lintas sejarah. Pembekalan Lawatan Sejarah Regional DIY (hal. 1-8). Yogyakarta: Balai Pelestarian Nilai dan Budaya Yogyakarta. 2006.

Surbakti, Ramlan. Memahami Ilmu Politik. Cet 6. Jakarta: Grasindo. 2007.

Susanti, Diyah Octorina., \& Effendi, Aan. Penelitian Hukum (Legal Research). Jakarta: Sinar Grafika. 2014.

Susilantini, E., Nurhajarini, D. R., \& Suyami. Serat Angger Pradata Awal dan Pradata Akir di Kraton Yogyakarta. Yogyakarta: BPNB. 2014

Williyanto, R. Pemerintahan DIY. Refomasi Birokrasi Pemerintahan Daerah Istimewa Yogyakarta. t.thn.

Yogyakarta, P.P. Pemerintah Daerah DIY. Dipetik Oktober 1, 2018, dari https://jogjaprov.go.id: https://jogjaprov.go.id/profil/3-sejarah. t.thn. 


\begin{abstract}
Asy-Syari'ah (P-ISSN : 2086-9029 E-ISSN: 2654-5675) is a periodical scientific journal that publishes various results of studies and research, literature review, and other scientific works whose scope covers the field of Islamic law/sharia, law and society in monodisciplinary, interdisciplinary, and multidisciplinary manners. The journal aims to expand and create innovative concepts, theories, paradigms, perspectives and methodologies in the above said scope. The Journal is published twice a year (june and december) by Faculty of Shariah and Law, Sunan Gunung Djati State Islamic University Bandung in collaboration with Asosiasi Sarjana Syariah Indonesia (ASSYI).
\end{abstract}

\title{
EDITORIAL OFFICE:
}

Fakultas Syariah dan Hukum UIN Sunan Gunung Djati Bandung Jl. Raya A.H. Nasution No. 105 Cibiru Kota Bandung, 40614

Tlp/Fax: +022-7802278 Faks. 022-7802278

Website http://journal.uinsgd.ac.id/index.php/asy-syariah/index

E-mail: Jurnalasy-syariah@uinsgd.ac.id 